THE

STORY

OF

STONE 
Post-

Contemporary

Interventions

Series Editors:

Stanley Fish and

Fredric Jameson 
Intertextuality,

THE

Ancient Chinese Stone Lore,

and the Stone Symbolism in

SUOR Dream of the Red Chamber,

Water Margin, and

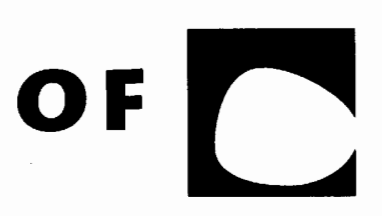

The Journey to the West

\section{JING WANG}

\section{STONE}

Duke University Press

Durham and London

1992 
수 1992 Duke University Press

All rights reserved

Printed in the United States of America

on acid-free paper $\infty$

Library of Congress Cataloging-in-

Publication Data appear on the last

printed page of this book.

Second printing, 2000 
For

Candice Rong-Rong Wei 
